\title{
PÓS-VERDADE: \\ A NOVA GUERRA CONTRA OS FATOS EM TEMPOS DE FAKE NEWS
}

\author{
POST-TRUTH:
}

THE NEW WAR ON TRUTH AND HOW TO FIGHT BACK

PÓS-VERDAD:

LA NUEVA GUERRA CONTRA LA VERDAD Y COMO CONTRAATACAR

Gilson Cruz Junior ${ }^{1}$

\section{RESUMO}

Este trabalho consiste em uma resenha crítica do livro "Pós-verdade: a nova guerra contra os fatos em tempos de Fake News".

PALAVRAS-CHAVE: Pós-verdade. Fake news. Informação. Conhecimento.

\section{ABSTRACT}

This paper is a critical review of the book "Post-truth: the new war on truth and how to fight back".

KEYWORDS: Post-truth. Fake news. Information. Knowledge.

\section{RESUMEN}

Este trabajo consiste en una resenha critica del libro "Pós-verdad: La nueva guerra contra la verdad y como contraatacar".

PALABRAS-CLAVE: Pós-verdad. Fake news. Información. Conocimiento.

\footnotetext{
${ }^{1}$ Doutor em Educação - Universidade Federal de Santa Catarina (UFSC) - Florianópolis, SC - Brasil. Professor adjunto - Instituto de Ciências da Educação - Universidade Federal do Oeste do Pará (ICED/UFOPA) - Santarém, PA - Brasil. E-mail: gijao05@hotmail.com

Submetido em: 30/06/2018 - Aceito em: 14/12/2018
}

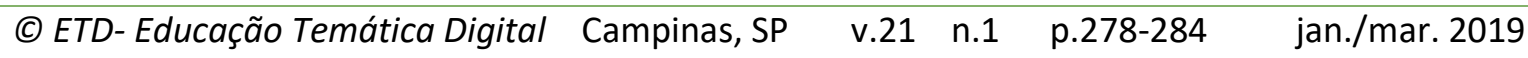


D'ANCONA, Matthew. Pós-verdade: a nova guerra contra os fatos em tempos de fake news. Barueri: Faro Editorial, 2018.

O Brasil é considerado, hoje, um dos países com maior número de produção, circulação e consumo de notícias falsas ${ }^{2}$ do mundo. A eleição presidencial de 2018 revelou o impacto decisivo exercido por boatos na configuração da opinião pública e na percepção dos eleitores em relação aos candidatos e às suas respectivas propostas. De acordo com o Relatório da Segurança Digital no Brasil ${ }^{3}$, intensificam-se os índices de detecção de notícias falsas no País: apenas do primeiro para o segundo trimestre do referido ano, houve um aumento de $50,6 \%$ na identificação de fake news, somando um total de 4,4 milhões de detecções - 1,5 milhão a mais que no trimestre anterior. Essa curva, explica o relatório, tende a ser ainda mais acentuada em períodos que abrangem grandes eventos, como a Copa do Mundo e as eleições presidenciais.

A despeito das questões que envolvem a ética jornalística, esse fenômeno vem adquirindo crescente atenção nos últimos anos, principalmente após a eleição presidencial dos Estados Unidos de 2016, quando as fake news foram apontadas entre os fatores determinantes para o desfecho do pleito. Desde então, elas se tornaram objeto de interesse em nível global, figurando na pauta acadêmica, jornalística e, inclusive, política, acionando temas fundamentais como a liberdade de expressão, o equilíbrio democrático e a natureza do conhecimento.

É nesse cenário que se insere o recém-lançado livro intitulado "Pós-verdade: a nova guerra contra os fatos em tempos de fake news", de Matthew d'Ancona. Nascido em 27 de janeiro de 1968, em Londres, Inglaterra, o jornalista, formado pela Universidade Oxford, tem em seu currículo passagens por entidades relevantes da imprensa britânica, como The Sunday Telegraph e The Spectator. Desde 2015, d'Ancona é colunista do folhetim inglês The Guardian, dedicando-se principalmente à cobertura de temas ligados à relação entre política e sociedade. Portanto, sua experiência e trajetória profissional estão diretamente vinculadas à problemática em discussão no livro.

De antemão, o autor explica que a pós-verdade não é sinônimo de fake news, já que, do ponto de vista histórico, a existência de notícias falsas não é um privilégio da contemporaneidade. Também não é equivalente à mentira, uma vez que, partindo do

\footnotetext{
2 Assim observa Pablo Ortellado, docente da Universidade de São Paulo, em entrevista concedida à Revista Veja. Mais detalhes Pablo (2018).

${ }^{3}$ Mais detalhes em DFNDR Lab (2018).
}

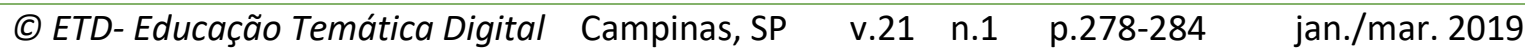


principal recorte definido pelo livro (o âmbito político), a criação e o emprego estratégico desse tipo de informação por parte de agentes públicos e governantes não é um fenômeno recente, possuindo rastros que remontam desde o antigo Império Romano ${ }^{4}$. Mesmo em regimes democráticos, a mentira é, segundo o autor, um elemento recorrente na política partidária.

Mas afinal, o que é a pós-verdade?

Eleita pelo Dicionário Oxford como a palavra do ano de 2016, sua primeira definição formal consiste em "Adj. Relacionado a ou denotando circunstâncias nas quais os fatos objetivos são menos influentes na opinião pública do que apelos à emoção e à crença pessoal" (MCINTYRE, 2018, p.5). Apesar da descrição categórica, o conceito de pós-verdade ainda é carente de grandes consensos. Esse fato se deve, em grande parte, ao seu caráter multifacetado e interdisciplinar, que aciona âmbitos como a política, psicologia, comunicação, educação e filosofia. Mcintyre (2018) ressalta que a pós-verdade é um campo de discussão constituído por uma complexa constelação de temáticas, em que podemos identificar fenômenos como: negacionismo científico, hiperpolarização política, vieses cognitivos, big data, mídias sociais, bolhas on-line e pós-modernidade. Desse modo, parece oportuno conceber a pós-verdade como um sistema dinâmico de ideias, proposta que, no âmbito do presente texto, reforça a necessidade de uma abordagem cautelosa e atenta ao itinerário de discussão da obra analisada.

No primeiro capítulo, d'Ancona apresenta a problemática da pós-verdade, tomando como base dois acontecimentos recentes que tiveram ampla repercussão mundial: a vitória de Donald Trump na eleição presidencial dos Estados Unidos e o Brexit ${ }^{5}$. Apesar do destaque, nenhum deles, afirma o autor, pode ser considerado a pedra fundamental da pós-verdade, uma vez que esse é um fenômeno complexo e decorrente da convergência de novos e antigos fatores.

Ao contrário do que postula o senso comum, a pós-verdade costuma estar menos associada à crescente inclinação da imprensa e dos políticos ao falseamento ou distorção da realidade do que às transformações no modo como o público lida com essa tendência. Tratase de uma alteração na percepção e no comportamento das pessoas no sentido de uma perda

4 Mais detalhes em Altares (2018).

5 Termo que resulta da combinação das palavras "Britain" (Bretanha) e "exit" (saída), aludindo ao processo de saída do Reino Unido da União Europeia, o qual foi iniciado após o desfecho do referendo que consultou os cidadãos ingleses sobre a desvinculação.

(C) ETD-Educação Temática Digital Campinas, SP $\quad$ v.21 $\quad$ n.1 $\quad$ p.278-284 jan./mar. 2019 
da primazia da verdade como princípio estruturante da sociedade e das decisões de interesse público e privado. Ou, como declara o próprio autor, de um tempo em que a indignação dá lugar à indiferença e, por fim, à conivência. As pessoas comuns, que outrora se viam confinadas à posição de vítimas e alvos passivos, atualmente exercem papel ativo em boa parte dos processos que alimentam e dão forma à pós-verdade.

A consolidação desse cenário obtém respaldo em um conjunto de constatações oriundas da Ciência Política contemporânea, abrangendo a cultura e o modo como os indivíduos tomam decisões envolvendo a adesão a ideias e os discursos. Uma das referências mencionadas é o blogueiro David Roberts, que apontou a existência de uma inversão na lógica que supostamente deveria conduzir esse processo:

\footnotetext{
Era reconfortante imaginar que os eleitores reuniam fatos, tiravam conclusões desses fatos, assumiam posições a respeito das questões com base em suas conclusões e escolhiam um partido político de forma correspondente. Na prática, escreveu Roberts, os eleitores escolhiam um partido com base em afiliações de valor, adotavam as opiniões da tribo, desenvolviam argumentos para apoiar essas opiniões e (só então) selecionavam fatos para reforçar essas alegações (D'ANCONA, 2018, p. 21).
}

No segundo capítulo, é apresentado mais um dos pilares da pós-verdade: a erosão da confiança. A segunda metade do século XX foi um período prenhe de escândalos que minaram a credibilidade da política partidária e da imprensa, não apenas ao arranhar suas reputações, mas principalmente por alimentar a crença na existência de um consórcio perverso entre elas. Trata-se, segundo o autor, de um conluio entre o governo e a "grande mídia" para ludibriar a população e escamotear manobras e interesses de setores de elite para garantir o status quo. Apesar de sua porção factível, esse imaginário deu margem à disseminação de um ceticismo neurótico em relação ao jornalismo institucionalizado e à esfera política.

Essa conjuntura também deu origem a manifestações pungentes de populismo que, diante de uma realidade cada vez mais complexa e instável, costumam se apresentar na forma de sistemas explicativos hipersimplificados, valendo-se de uma linguagem notadamente maniqueísta, polarizadora e com forte apelo emocional. A esse fato somam-se a ascensão e a consolidação da web 2.0: paradigma em que os usuários da rede mundial de computadores deixam de ser meros consumidores de informação, adquirindo o status de produtores de conteúdo, graças a uma gama cada vez maior de ferramentas e recursos criativos altamente acessíveis. Assim, atividades que antes eram exclusivamente realizadas por profissionais, como o próprio jornalismo, tornaram-se disponíveis para as pessoas comuns. Entre os efeitos dessa mudança, destacam-se o aumento exponencial na oferta de informações e a queda inversamente proporcional da qualidade e confiabilidade dos

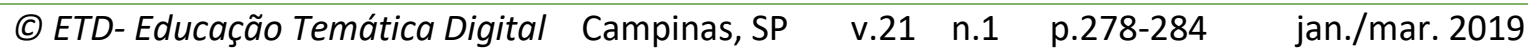


conteúdos em questão, fator que costuma estar intimamente ligado à emergência das fake news.

D'Ancona esclarece que essa nova dinâmica alterou sensivelmente o modo de participação popular no âmbito das democracias representativas:

O século XX deixou como herança um sistema de instituições baseadas em regras e em evolução gradual; e uma hierarquia de conhecimento e autoridade, em que entidades representativas interagiam com o estado de acordo com protocolos comprovados. Hoje essa estrutura está sendo desafiada por uma malha de redes vinculadas não por laços institucionais, mas pelo poder viral da mídia social, do ciberespaço e dos sites, que se deleitam em sua repugnância em relação à grande mídia (D’ANCONA, 2018, p. 63).

O terceiro capítulo discorre sobre a paranoia conspiracionista e o negacionismo científico. No contexto da pós-verdade, esses fenômenos tendem a operar de forma integrada, podendo, nesse caso, ser ilustrados por duas iniciativas distintas: 1) o movimento antivacina (antivaxx, grupo que se recusa a aderir a qualquer forma de imunização coletiva ou individual, devido à crença que existe um complô arquitetado pela indústria farmacêutica com a anuência do estado e cujo objetivo é ocultar supostos efeitos colaterais das vacinas sobre a população, como o aumento nos índices de crianças com autismo; e 2) a negação do holocausto, que consiste em um movimento ideológico com orientação antissemita que tem como propósito deslegitimar ou mesmo rejeitar por completo o consenso históricoacadêmico a respeito da factualidade da perseguição e do extermínio de judeus em campos de concentração durante o Terceiro Reich.

Apesar de suas diferenças aparentes, ambos compartilham princípios como a fundamentação pseudocientífica produzida por "especialistas" que, não raro, manipulam de modo antiético métodos e instrumentos de investigação. Ainda assim, o principal fator que parece impedir que esses dados caiam em descrédito e posterior esquecimento é a sua apropriação e uso estratégico por influencers e formadores de opinião que, no âmbito da cultura digital e das redes sociais, costumam capitalizar atenção e seguidores com o auxílio de uma retórica alarmista e, por consequência, revestida de um forte apelo mobilizador.

Na busca das raízes epistêmicas da pós-verdade, o quarto capítulo centra atenções na noção de pós-modernidade. Tal como pensado por Jean François Lyotard (1988), o pósmoderno delimita a condição da cultura contemporânea que se caracteriza pela crise dos relatos de cunho filosófico-metafísico, mais precisamente às suas pretensões atemporais e universalizantes. Segundo o autor, essa premissa envolve, dentre outros aspectos, um conjunto de transformações relativas às posições de saber e às regras do jogo da ciência.

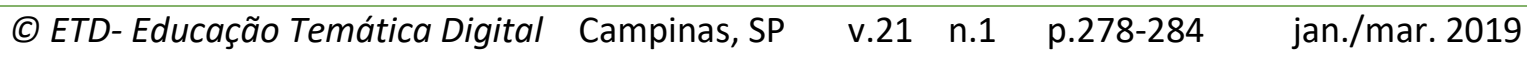


Dentre as principais vítimas desse movimento está a metanarrativa iluminista, que estabelece o progresso gradual da humanidade com base no uso consciente da razão, que tem na ciência o seu principal baluarte, haja vista sua capacidade de produzir um conhecimento que promova a ruptura com formas de pensamento mágico e obscurantista. Entretanto, a ciência moderna tem sido frequentemente questionada em sua pretensão como via de acesso privilegiada a um saber-verdade, enquanto as próprias condições de possibilidade de uma verdade que expressa o real em sua forma transcendente atritam com a crença cada vez mais difundida na existência de múltiplas comunidades interpretativas, cada qual constituída por seus jogos de linguagem e verdades particulares.

Em outras palavras, o relativismo cognitivo associado à pós-modernidade impõe uma espécie de pacto anticomunitário. A realidade passa a ser vista como uma esfera tão elusiva, cheia de meandros, de perspectivas divergentes e de grupos heterogêneos, que a busca pela verdade já não representa mais uma missão prioritária. Nesse ambiente florescem discursos pluralistas em que o escrutínio crítico de evidências, cada vez mais, dá lugar à escolha de "times" aos quais pertencer e cujas narrativas devem ser subscritas e propagadas.

No quinto e último capítulo estão esboçados alguns dos desafios e modos de resistência às armadilhas da pós-verdade. Dentre os apontamentos mais relevantes, destacam-se: 1) cada indivíduo deve exercitar uma postura crítica e dialógica com a informação disponível, desenvolvendo e mobilizando competências de filtragem, checagem e avaliação; 2) é importante planejar e implementar políticas, ações específicas e soluções tecnológico-algorítmicas capazes de auxiliar usuários, espectadores e consumidores na tarefa de aferir a natureza e a confiabilidade dos conteúdos veiculados nas mídias, por exemplo, sob a forma de agências e dispositivos de fact-checking; e 3) tendo em vista que a factualidade e a consistência da informação nem sempre são o bastante para fazer frente ao arsenal da pósverdade, o combate às fake news e à pseudociência também precisa incorporar formas de comunicação e divulgação dotadas de narratividade capaz de apelar às emoções, ou seja, trata-se de não somente falar às mentes, mas também aos corações.

Em linhas gerais, o livro analisado trata de uma temática emergente, complexa e altamente entranhada no cotidiano da sociedade da informação. Para lidar com os espinhos da pós-verdade, o autor adotou um discurso engajado e combativo, no qual o fenômeno é encarado como um problema a ser superado e, antes disso, compreendido. Nesse sentido, o trabalho em questão pode decepcionar aqueles que buscam uma incursão teórico-conceitual aprofundada, uma vez que incorpora um tom notadamente descritivo e centrado em relatos de situações concretas e eventos recentes.

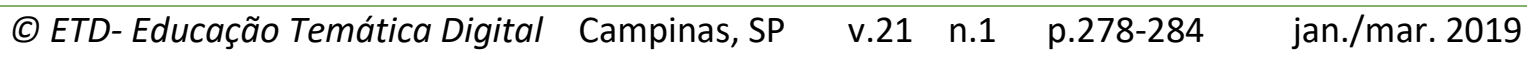


Por outro lado, levando em consideração a escassa literatura sobre o assunto disponível em língua portuguesa, o livro de d'Ancona apresenta-se como uma introdução altamente acessível e recomendada ao grande público. Além disso, mesmo baseado em ocorrências radicadas no âmbito europeu e estadunidense, esse debate abre caminhos para o estabelecimento de analogias entre tendências globais e internacionais da pós-verdade e o contexto brasileiro. Demarcar tais especificidades é um esforço essencial à compreensão das manifestações mais preocupantes do fenômeno, como a erosão da confiança da sociedade nas instituições. O Estado, a grande imprensa, as escolas e as universidades se convertem em alvos de um crescente descrédito popular que, por sua vez, está implicado na ascensão e popularidade de problemáticas como fake news, negacionismo científico, revisionismo histórico e populismo nacionalista. Diante disso, um dos principais desafios para os estudos sobre o tema envolve a tarefa de sintonizar as teorizações atuais de pós-verdade com as raízes históricas e as matrizes culturais do Brasil e da América Latina, para assim subsidiar a formulação de estratégias de resistência e enfrentamento ao cada vez mais generalizado ecossistema da desinformação.

\section{REFERÊNCIAS BIBLIOGRÁFICAS}

ALTARES, Guillermo. A longa história das notícias falsas. El Pais, Madrid, 18 de jun. 2018. Disponível: https://brasil.elpais.com/brasil/2018/06/08/cultura/1528467298 389944.html . Acesso em: $10 \mathrm{de}$ out. 2018.

DFNDR LAB. Relatório da segurança digital no Brasil: segundo trimestre de 2018. 2018. Disponível em: https://www.psafe.com/dfndr-lab/wp-content/uploads/2018/08/Relat\%C3\%B3rio-daSeguran\%C3\%A7a-Digital-no-Brasil-2-trimestre-2018.pdf . Acesso em: 2 de out. de 2018

LYOTARD, Jean François. O pós-moderno. Rio de Janeiro: José Olímpio, 1988.

MCINTYRE, Lee. Post-truth. Cambridge, MA: MIT Press, 2018.

PABLO Ortellado: Brasil esteve na 'vanguarda' das fake news. Veja, São Paulo, 11 de mai. 2018. Disponível em: https://veja.abril.com.br/tveja/em-pauta/pablo-ortellado-brasil-esteve-navanguarda-das-fake-news/. Acesso em: 8 de out. 2018.

Revisão gramatical do texto sob responsabilidade de: Eliane Ventura E-mail: elianeventura@yahoo.com 